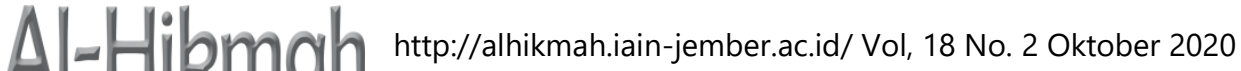 P-ISSN:1907-4328, E-ISSN : 2685-4376/P. 169-188
}

\section{Moderasi Beragama: \\ Meninjau Hadis-Hadis Hukuman Mati bagi Orang Murtad}

\author{
Nasirudin Al Ahsani \\ Institut Agama Islam Negeri Jember \\ nasirudin@iain-jember.ac.id
}

\begin{abstract}
Islam is a religion that gives mercy to all creation, a religion that teaches peace, safety and prosperity. In recent years, there have been many wicked individuals trying to destroy Islam. Unlike in the past where waging war on Islam were done only with swords, today's war against Islam is more powerful, that is by planting seeds of doubt in every Muslim's heart. Both in terms of aqidah (Creed) and Sharia (Islamic law). The current study is a library research. The main sources of this research data were taken from the kutub al sittah (the authentic six): Sahịị Bukhārī, Șaḥ̄h Muslim, Sunan Ab̄̄ Dāwūd, Sunan al-Nasā̀i, Sunan al-Tirmidhi, and Sunan Ibn Mājah. Meanwhile, the secondary sources were taken from the takhrij and shurūh al-hadith books. The conclusion of the current study reveals that the death penalty for those who turn back from Islam or apostates can be applied if they meet two conditions: 1) Leaving Islam either by word or deed; 2) Committing criminal acts, such as: dividing Muslims, creating chaos, damage, disobeying the state, and helping the enemy in fighting the Muslims. The author concludes that neither the verses in the Qur'an nor the hadiths of the Prophet PBUH immediately order the killing of a person who turns back from Islam, unless that person commits insubordination, is in league with the enemy and other similar things.
\end{abstract}

Keywords: Hadith, Death Penalty, Murtadd

\begin{abstract}
Abstrak
Islam adalah agama yang memberikan rahmat kepada seluruh makhluk, agama yang mengajarkan kedamaian, keselamatan dan kesejahteraan. Dalam beberapa tahun terakhir, ada banyak orang jahat yang mencoba menghancurkan Islam. Tidak seperti dulu yang berperang melawan Islam hanya dilakukan dengan pedang, perang melawan Islam saat ini lebih dahsyat, yaitu dengan menanam benih keraguan di hati setiap muslim. Baik dari segi aqidah (Aqidah) maupun Syariah (hukum Islam). Penelitian saat ini adalah penelitian kepustakaan. Sumber utama data penelitian ini diambil dari kutub al sittah (enam yang otentik): Șaḥị̣ Bukhār, Șahịḥ Muslim, Sunan Abī Dāwūd, Sunan al-Nasā'i, Sunan al-Tirmidzi, dan Sunan Ibn Mājah. Sedangkan sumber sekunder diambil dari kitab takhrij dan syuro al-hadits. Kesimpulan dari penelitian ini mengungkapkan bahwa hukuman mati bagi mereka yang murtad atau murtad dapat diterapkan jika memenuhi dua syarat: 1) Keluar dari Islam baik dengan perkataan maupun perbuatan; 2) Melakukan tindakan kriminal, seperti: memecah belah umat Islam, membuat kekacauan, merusak, mendurhakai negara, dan membantu musuh dalam memerangi umat Islam. Penulis menyimpulkan bahwa baik
\end{abstract}


ayat-ayat Al-Qur'an maupun hadits Nabi tidak langsung memerintahkan pembunuhan orang yang murtad, kecuali orang itu melakukan pembangkangan, bersekutu dengan musuh dan hal-hal serupa lainnya.

Kata kunci: Hadis, Hukuman Mati, Murtadd

\section{Pendahuluan}

Islam merupakan agama rahmat bagi seluruh alam, agama yang mengajarkan kedamaian, keselematan dan kesejahteraan. Rasulullah sebagai Rasul berlaku lemah lembut kepada setiap insan, tidak pandang bulu, baik kaya maupun miskin, tua maupun muda selalu mendapat perlakuan yang sama dan istimewa dari Rasulullah

Dewasa ini, banyak oknum-oknum yang berusaha untuk menghancurkan Islam. Tidak seperti zaman dahulu, peperangan hanya dilakukan dengan pedang, tetapi zaman sekarang lebih dahsyat lagi, yaitu dengan menimbulkan benih-benih keraguan ke dalam setiap Muslim. Baik dalam hal aqidah maupun Syari'ah.

Salah satu yang menjadi sasaran empuk adalah hadis yang berkenaan dengan perintah membunuh orang yang keluar dari Islam (murtad). Dengan hadis tersebut musuh-musuh Islam berusaha untuk menjadikan kesan Islam merupakan agama yang radikal, sehingga menjadikan orang-orang Islam sebagai musuh bersama. Dengan begitu, Islam akan sulit berkembang dan diterima baik di belahan bumi timur maupun barat.

Dalam makalah ini, penulis berusaha menelusuri sumber hadis tersebut, serta melakukan komparasi dengan hadis-hadis yang senada, sehingga memiliki data yang valid dan jelas terkait hadis tersebut. Tidak hanya itu, penulis juga meneliti syarh (penjelasan) dari para ulama yang kompeten dalam bidangnya, agar mendapatkan pemahaman yang lurus dan sempurna.

\section{Metode Penelitian}

Penelitian ini merupakan riset kepustakaan (Library Research). Sumber utama penelitian ini diambil dari kutub sittah: Șaḥị̣ Bukhārī, Șahịḥ Muslim, Sunan Abī Dāwūd, Sunan al-Nasā̀i, Sunan al-Tirmidhi, dan Sunan Ibn Mājah. Sedangkan sumber sekunder diambil dari kitab-kitab takhrij dan shurūh al-hadīth.

\section{Pembahasan}

Menurut al-'Azady, Riddah secara etimologis adalah الرجوع عن الثيع, yaitu kembali dari sesuatu. Sedangkan dalam kamus lisan al-'arab riddah adalah التحول, yakni berubah. ${ }^{1}$

Sedangkan pengertian riddah secara terminologis adalah sebagai berikut:

${ }^{1} \mathrm{Nu}$ 'man 'Abdurrazzaq, Ahkam al-Murtad fi al-Syari'ah al-Islamiyyah (Riyadl: Dar al'Ulum, 1983), 19 
1. Menurut al-Samarqandi dari Hanafiyyah: Riddah adalah isitlah yang digunakan untuk kembali (berpaling) dari keimanan.

2. Al-Qarrafy: Riddah adalah istilah yang digunakan untuk terputusnya Islam dari seorang mukallaf.

3. Menurut 'Alisy: Riddah adalah kafirnya seorang Muslim dengan perkataan yang sharih atau lafal yang menunjukkan hal tersebut atau perbuatan yang mengandung kekafiran.

4. Menurut Qalyuby dari Syafi 'iyyah: Riddah adalah memutuskan keislaman dengan niat kafir, atau perkataan kekafiran atau perbuatan, baik itu untuk mengolok-olok, melawan, ataupun secara kepercayaan.

Dari keempat pengertian di atas, menurut $\mathrm{Nu}^{\text {'man }}$ 'Abdurrazzaq definisi yang Jami ' Mani' adalah yang diberikan oleh Qalyuby ${ }^{2}$. Oleh karenanya, seseorang dapat dikatakan murtad karena empat sebab:

1. Murtad dalam aqidah. Para ulama bersepekat bahwa barangsiapa yang mempersekutukan Allah 此, mengingkari-Nya, menolak salah satu sifat yang tetap dari sifatnya, atau menganggap Allah mempunyai anak, maka dihukumi kafir.

2. Murtad dalam perkataan. Yaitu dengan menghina Allah dan rasulnya. Allah 能 berfirman: Dan jikalau engkau bertanya tentang kelakuan mereka, pastilah mereka jawab, "Sesungguhnya kami hanyalah bersenda gurau dan bermainmain saja". Maka katakanlah: "Apakah dengan Allah, ayat-ayat-Nya dan RasulNya kamu selalu berolok-olok? [At Tawbah65]

3. Murtad dalam perbuatan. Para ulama bersepakat barangsiapa yang sujud untuk menyembah berhala, matahari ataupun bulan maka kafir.

4. Murtad dalam meninggalkan kewajiban agama. Yaitu apabila seseorang meninggalkan shalat (ingkar) maka dia telah keluar dari Islam. Begitu juga apabila meninggal zakat, puasa dan haji (dengan maksud ingkar), maka para ulama sepakat akan kekafirannya. ${ }^{3}$

Sedangkan syarat seseorang dapat dihukumi sebagai orang yang keluar dari agama Islam (murtad) ada tiga, yaitu: baligh, berakal dan tidak terpaksa (اختيار).4

\section{Takhrij hadis, serta tinjauan Sanad hadis dan Matannya}

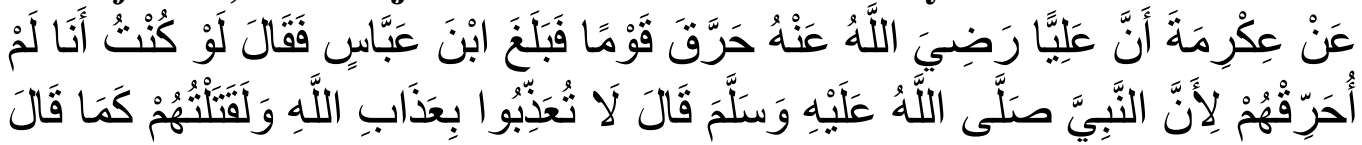

${ }^{2}$ Ibid., 37.

${ }^{3}$ Wizaratul al-Awqaf Kuwaitiyyah, Mausu'ah Kuwaitiyyah, Jilid 22 (Kuwait: Wizaratu alAuqaf wa al-Syu'un al-Islamiyyah, 2007), 184.

${ }^{4}$ Ibid. 180. 


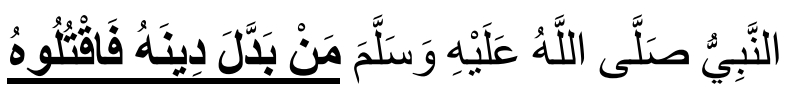

Dari 'Ikrimah sesungguhnya 'Ali pernah membakar suatu kaum, kemudian hal tersebut terdengar oleh 'Abdullah ibn 'Abbas', lalu 'Abdullah Ibnu Abbas berkata: "Jika aku ada (di tempat tersebut), tentu aku tidak akan membakar mereka karena Nabi telah bersabda: "Janganlah kalian menyiksa dengan siksaan Allah (dengan api) ". Dan aku hanya akan membunuh mereka sebagaimana Nabi telah bersabda: "Siapa yang mengganti agamanya maka bunuhah dia". ${ }^{6}$

1. Takhrij hadis

Dengan menggunakan Mu'jam Mufahras li Alfadzi al-Hadis, penulis menggunakan keyword فـ فـتّلوه untuk mencari hadis ini, hasilnya hadis ini ditemukan pada:

a. Shahih Bukhari, kitab Jihad, bab 149; kitab istitabah, bab 2; kitab i'tishab, bab 28;

b. Sunan Abi Dawud, kitab Hudud, bab 1;

c. Sunan Tirmidzi, pada kitab Hudud, bab 25;

d. Dalam Sunan al-Nasa'i, kitab Tahrim, bab 14;

e. Diriwayatkan Ibn Majah, kitab Hudud, bab 2;

f. Musnad Ahmad, Juz 1, hal. 217, 283, 323; Juz 2, hal. $231 .^{7}$

2. Kritik Sanad

Imam Bukhari dalam Shahihnya menggunakan sanad sebagai berikut:

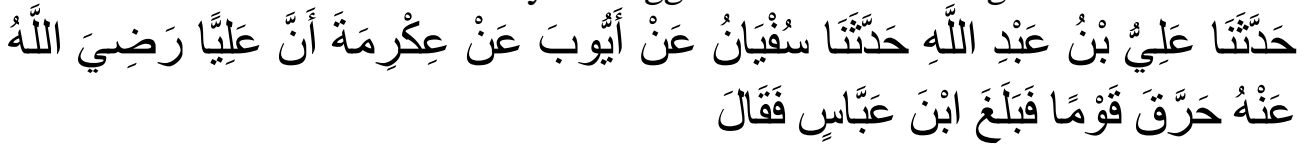

Berikut adalah kritik pada tiap perawi (urut dari sahabat):

a. Ibn 'Abbas: ${ }^{8}$

1) Nama lengkap: 'Abdullah ibn 'Abbas ibn 'Abdul Muththalib al-Qursyi alHasyimi.

2) Julukan: al-Hibr dan al-Bahr karena keluasan ilmunya. 'Abdullah ibn Mas'ud mengatakan: "Iya, "Abdullah ibn 'Abbas adalah turjuman alQur'an".

3) Meriwayatkan dari: Rasulullah

${ }^{5}$ Ketika itu ibn 'Abbas menjadi gubernur Bashrah. Lihat: Mubarakfuri, Tuhfatu al-Ahwadzi, Jilid 5 (Beirut: Dar al-Kutub al-'Ilmiyyah, t.th.), 19.

${ }^{6}$ Muhammad ibn Isma'il al-Bukhari, Shahih Bukhari, Jilid 2, No. Hadis 3054 (Stuttgart: Jam'iyyatu al-Maknaz al-Islami, 2000), 584.

${ }^{7}$ Wensink, al-Mu 'jam al-Mufahras li Alfadzi al-Hadis, juz 5 (Leiden: Bril, 1936), 287. 1980), 154.

${ }^{8}$ Al-Mizzi, Tahdzib al-Kamal fi Asma'i al-Rijal, juz 15 (Beirut: Mu'assasah al-Risalah, 
Buraidah ibn al-Hashib al-'Aslami, Tamim al-Dari dsb.

4) Yang meriwayatkan darinya: Ibrahim ibn 'Abdullah ibn Ma'bad ibn 'Abbas, al-'Arqam ibn Syurahbil al-'Awdy, 'Isyaq ibn 'Abdullah ibn Kinanah, 'Anas ibn Malik, 'krimah, 'Alqamah dsb.

b. 'Ikrimah:'

1) Nama lengkap: 'Ikrimah al-Qursyi al-Hasyimi, Abu 'Abdullah al-Madani. Ia merupakan pelayan ibn 'Abbas. ia berasal dari Barbar, penduduk Maroko.

2) Meriwayakan dari: Jabir ibn 'Abdullah, al-Hajjaj ibn 'Amru al-'Anshari, alHasan ibn 'Ali ibn Abi Talib, 'Abdullah ibn 'Abbas, 'Abdullah ibn 'Umar ibn al-Khaththab, 'Abdullah ibn 'Amru ibn al-'Ash, 'Ali ibn Abi Talib, Abu Hurairah, 'Aisyah dsb.

3) Yang meriwayatkan darinya: 'Abban ibn $\mathrm{S}\left\{\mathrm{am}^{6} \mathrm{ah}\right.$, Ibrahim al-Nukh'i, 'Isyaq ibn 'Abdullah ibn Jabir, Isma'il ibn Abi Khalid, 'Ayyub alSakhtiyani, Badr ibn Utsman, Ja'far ibn Rabi'ah dsb.

4) Kritik:

a) Qatadah: Orang paling 'alim di kalangan tabi 'in ada empat: 'Atha' ibn Abi Rabah yang paling paham tentang manasik, Sa'id ibn Jabir paling paham tentang tafsir, 'Ikrimah paling paham tentang sirah Nabi, alHasan paling paham tentang halal dan haram.

b) 'Ali ibn al-Madini dari Yahya ibn Sa'id: 'Ashhab ibn 'Abbas enam: Mujahid, Tawus, 'Atha', Sa'id ibn Jabir, 'Ikrimah, Jabir ibn Zayd.

c) Al-Bukhari: laisa ahadun min 'ashhabina illa wa huwa yuhtajju bi 'ikrimah.

d) Al-Nasa'i: tsiqah.

5) Meninggal: Imam Bukhari dan Ya'qub ibn Sufyan dari 'Ali ibn al-Madini: Meninggal di Madinah tahun $104 \mathrm{H}$.

c. 'Ayyub: ${ }^{10}$

1) Nama lengkap: 'Ayyub ibn Abi Tamimah, namanya Kaisan, al-Sakhtiyani, Abu Bakr al-Bashri.

2) Diriwayatkan dari: Ibrahim ibn Murrah, Ibrahim ibn Maysarah al-Ta'ifi, alHasan al-Bashri, Hamid ibn Hilal al-'Aduwwy, Zaid ibn 'Aslam, 'Abdullah ibn Syaqiq, 'Abdullah ibn 'Ubadillah ibn Abi Malikah, 'Abdurrahman alQasim, 'Ikrimah ibn Khalid al-Makhzumi, 'Ikrimah pelayan ibn 'Abbas, 'Amru ibn Dinar dsb.

3) Yang meriwayatkan darinya: Ibrahim ibn Tahman, Isma'il ibn 'Iliyyah, Jarir ibn Hazim, Hammad ibn Salamah, Sa'id ibn 'Arubah, Sufyan alTsaury, Sufyan ibn 'Uyaynah, Syu'bah ibn al-Hajjaj dsb.

\footnotetext{
${ }^{9}$ Ibid., juz 20, 264.

${ }^{10}$ Ibid., juz 3, 457.
} 
4) Kritik:

a) Muhammad ibn Sa'd: Tsiqah tsabat fi al-hadis, Katsir al-'ilm, hujjah, 'adlan

b) Abu Hatim: tsiqah la yus'alu 'an mitslihi

c) Al-Nasa'i: tsiqah tsabat

5) Meninggal: dari al-Bukhari dari 'Ali ibn al-Madini: meninggal tahun $131 \mathrm{H}$. Dikatakan: umurnya 63 tahun.

d. Sufyan: ${ }^{11}$

1) Nama lengkap: Sufyan ibn 'Uyaynah ibn Abi 'Imran, namanya Maymun alHilaly, Abu Muhammad al-Kufi.

2) Meriwayatkan dari: Ibrahim ibn 'Uqbah, Ibrahim ibn Muhammad alMuntasyir, Ibrahim ibn Maysarah, 'Ayyub ibn Abi Tamimah, 'Ayyub ibn Musa, Sufyan al-Tsawry, Abu Hazim Salamah ibn Dinar, 'Abdullah ibn Dinar dsb.

3) Yang meriwayatkan darinya: Ibrahim ibn Sa'id al-Jawhary, Abu 'Isyaq Ibrahim ibn Muhammad al-Fazari, Ahmad ibn Hanbal, Ahmad ibn S\{alih al-Mishry, Bisyr ibn al-Hakam al-Naysaburi, Sufyan al-Tsawry (gurunya), 'Abdurrahman ibn Mahdi, 'Ali ibn al-Madini, 'Ammar ibn Khalid alWasithi dsb.

4) Kritik:

a) Harmalah ibn Yahya, aku mendengar Syafi'i berkata: Tidak pernah ku lihat seorang pun yang lebih ahli dari Sufyan ibn 'Uyaynah, dan tidak pernah aku melihat seseorang yang ilmunya cukup untuk memberi fatwa daripadanya.

b) Ahmad ibn Hanbal: Apabila Sufyan ibn 'Uyaynah ditanya tentang manasik maka ia akan dengan mudah menjawabnya, tetapi jika ditanya tentang permasalhan thalaq maka ia sangat berhati-hati.

c) Ibn Wahb: Aku tidak pernah melihat seseorang yang paling paham Alquran dari ibn 'Uyaynah.

5) Lahir: $10 \mathrm{H}$

6) Wafat: Hari Sabtu, tanggal 1 Rajab 198 H.

e. 'Ali ibn 'Abdullah al-Madini'

1) Nama lengkap: 'Ali ibn 'Abdullah ibn Ja'far ibn Najih al-Sa'di.

2) Meriwayatkan dari: 'Azhar ibn Sa'd al-Samman, al-'Aswad ibn 'Amir Syadzan, 'Umayyah ibn Khalid, Sufyan ibn 'Uyaynah, Sa'id ibn 'Amir, dsb.

3) Yang meriwayatkan darinya: Imam Bukhari, Abu Dawud, Ibrahim ibn alHarits al-Baghdadi, Ahmad ibn Hanbal, Sufyan ibn 'Uyaynah (gurunya),

\footnotetext{
${ }^{11}$ Ibid., juz 11, 177.

${ }^{12}$ Ibid., juz 21, 5.
} 
Moderasi Beragama: Meninjau Hadis-Hadis Hukuman Mati Bagi Orang Murtad

SHalih ibn Ahmad ibn Hanbal dsb.

4) Kritik:

a) Abu Hatim al-Razi: 'Ali paling paham tentang hadis dan illatnya.

b) Muhammad ibn Utsman ibn Abi Syaibah berkata: 2 bulan sebelum meninggalnya ibnu al-Madini, aku mendengar ia berkata: Alquran merupakan kalamullah bukan makhluq dan barangsiapa yang mengatakan makhluq maka dia kafir.

5) Meninggal: al-Bukhari mengatakan: al-Madini wafat pada tahun $234 \mathrm{H}$

3. Kritik Matan

a. Imam Bukhari meriwayatkan dengan lafal

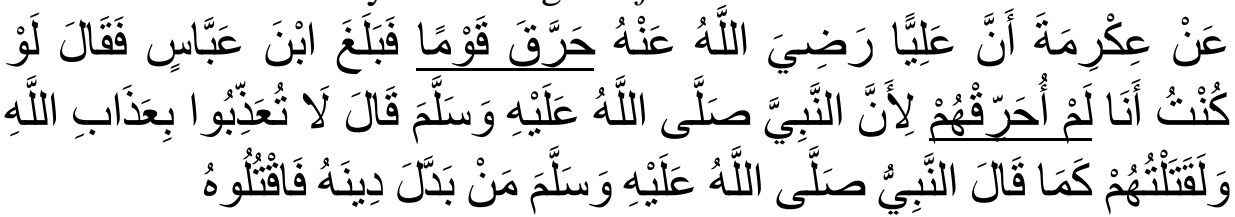

Dari 'Ikrimah bahwa 'Ali membakar suatu kaum lalu berita itu sampai kepada ibn 'Abbas maka dia berkata: "Seandainya aku ada, tentu aku tidak akan membakar mereka karena Nabi telah bersabda: "Janganlah kalian menyiksa dengan siksaan Allah (dengan api) ". Dan aku hanya akan membunuh mereka sebagaimana Nabi telah bersabda: "Siapa yang mengganti agamanya maka bunuhah dia". ${ }^{13}$

Dari matan di atas, dapat beberapa poin penting yang perlu diperhatikan:

1) Pada lafal di atas tidak dijelaskan kaum yang dibakar 'Ali, sedangkan pada riwayat yang lain dijelaskan bahwa yang dibakar 'Ali adalah orang-orang yang murtad.

2) Pada matan Bukhari menggunakan lafal لَحْ أُحَرِ فْهُهْ sedangkan dalam riwayat lain tidak menggunakan lafal tersebut (لم أكن لأحرقهم).

b. Dalam Sunan Tirmidzi menggunakan lafal

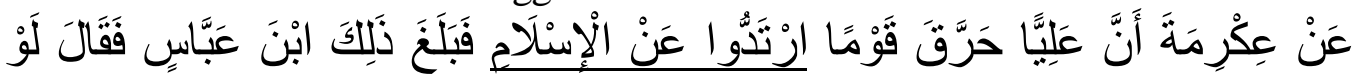

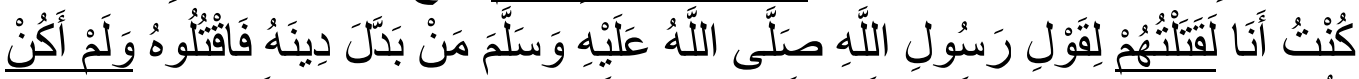

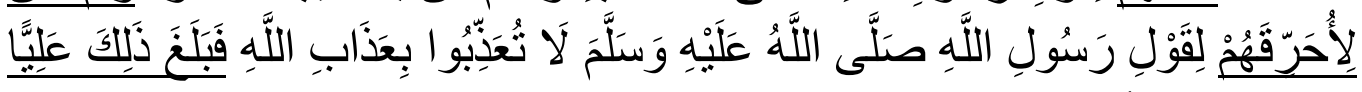

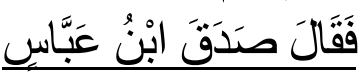

Dari 'Ikrimah bahwa 'Ali pernah membakar sebuah kaum yang murtad dari Islam, hal itu sampai kepada ibn 'Abbas, ia pun berkata; Seandainya itu aku, niscaya aku

${ }^{13}$ Muhammad ibn Isma'il al-Bukhari, Shahih Bukhari, Jilid 2, No. Hadis 3054, 584. 
akan membunuhnya, sebagaimana sabda Rasulullah "Barangsiapa yang mengganti agamanya (murtad), maka bunuhlah dia." Dan aku tidak akan membakar mereka, berdasarkan sabda Rasulullah "Janganlah kalian mengadzab dengan adzab Allah." Hal itu sampai juga kepada Ali, ia pun berkata; Ibnu Abbas benar. ${ }^{14}$

Dari matan di atas, dapat beberapa poin penting yang perlu diperhatikan:

1) Pada lafal di atas dijelaskan bahwa orang yang dibakar 'Ali adalah orang-orang yang murtad.

2) Pada matan Sunan Tirmidzi menggunakan lafal لـم أكن لأحرقهم aku akan membunuhnya), sedangkan dalam Shahih Bukhari menggunakan lafal لََْْ أُحرِِّ فْهُ (aku tidak akan membakarnya).

3) Terdapat kalimat pada sunan Tirmidzi yang tidak ada dalam riwayat Bukhari,

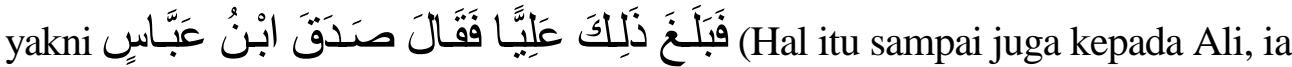
pun berkata; Ibnu Abbas benar).

c. Dalam Sunan Abi Dawud ${ }^{15}$ dan Musnad Ahmad. ${ }^{16}$

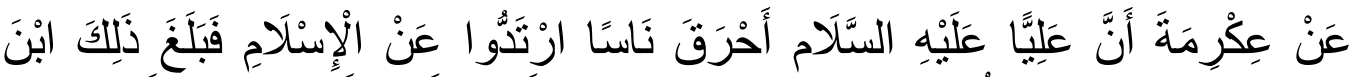

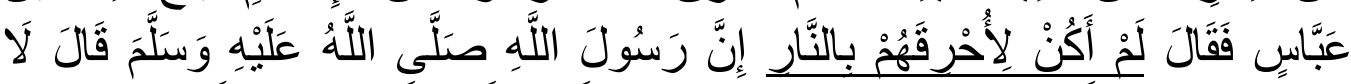

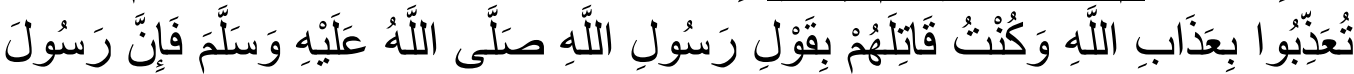

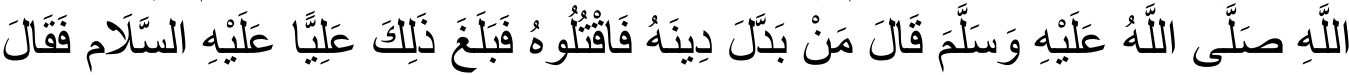

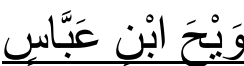

Dari 'Ikrimah bahwa 'Ali pernah membakar orang-orang yang murtad dari Islam. Lalu sampailah berita itu kepada ibn 'Abbas hingga ia berkata, "Aku tidak akan pernah menghukum mereka dengan cara membakar karena Rasulullah bersabda: "Janganlah kalian menyiksa dengan siksaan Allah." dan aku memerangi mereka berdasarkan sabda Rasulullah "Barangsiapa mengganti agamanya, maka bunuhlah ia." Berita tersebut terdengar sampai ke telinga 'Ali, lalu ia berkata, "Ibn 'Abbas benar."

${ }^{14}$ Imam Tirmidzi, Sunan al-Tirmidzi, Jilid 1, No. Hadis 1530 (Stuttgart: Jam‘iyyatu alMaknaz al-Islami, 2000), 395.

${ }^{15}$ Abu Dawud, Sunan Abi Dawud, Jilid 2, No. Hadis 4353 (Stuttgart: Jam‘iyyatu al-Maknaz al-Islami, 2000), 726.

${ }^{16}$ Imam Ahmad ibn Hanbal, Musnad Ahmad, Tahqiq: Syu'aib Arna'uth, Jilid 4, No. Hadis 2552 (Beirut: Mu'assasah al-Risalah, 1999), 336.

176 | Nasirudin Al Ahsani 
Dari matan tersebut, terdapat beberapa hal yang perlu diperhatikan:

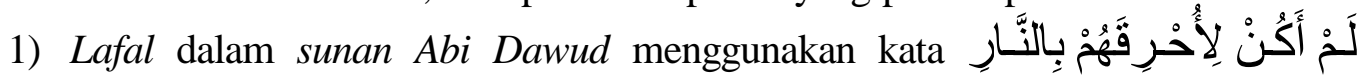

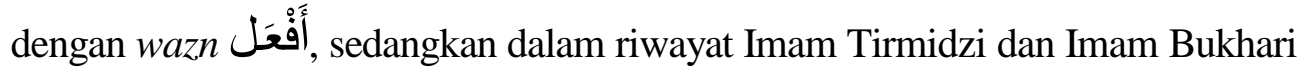
dengan wazn فَعَّ人َ

2) Abu Dawud meriwayatkan dengan lafal وَنْخَ ابْنِ عَبَّاسِ (Ibn 'Abbas benar) sebagaimana diriwayatkan pula oleh Imam Tirmidzi dengan lafal صَدَقَ ابْنْ عَبَّاسِ Dalam riwayat Imam Bukhari pembenaran 'Ali bin Abi Thalib kepada ibn 'Abbas tidak ditemukan.

d. Dalam Sunan al-Nasa'i ${ }^{17}$ dan Musnad Ahmad ${ }^{18}$

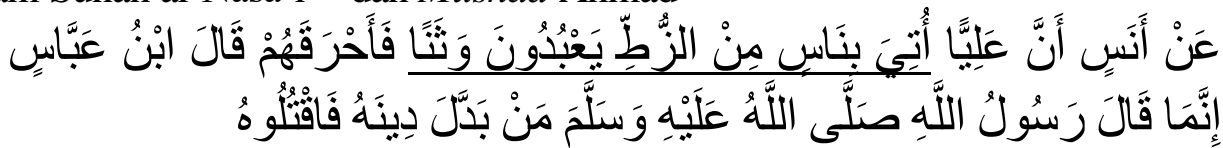

Dari Anas sesungguhnya beberapa orang al-Zuth yang menyembah berhala dihadapkan kepada 'Ali bin Abi Thalib. Lalu ia membakar orang-orang tersebut. Ibn 'Abbas berkata; Rasulullah telah bersabda: "Barangsiapa yang menganti agamanya (keluar dari agama Islam), bunuhlah ia."

Beberapa hal penting dari matan tersebut adalah:

1) Orang dari al-Zuth yang dibakar oleh 'Ali bin Abi Thalib

2) Orang-orang tersebut murtad dari agama Islam, kemudian menyembah berhala.

e. Dalam Musnad Ahmad

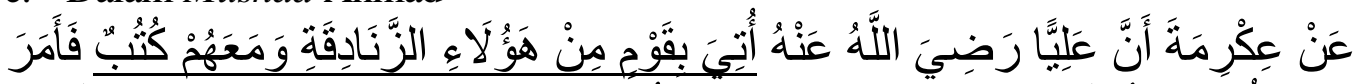

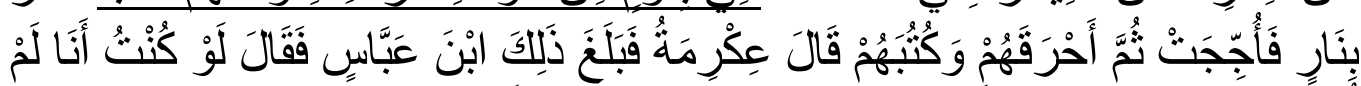

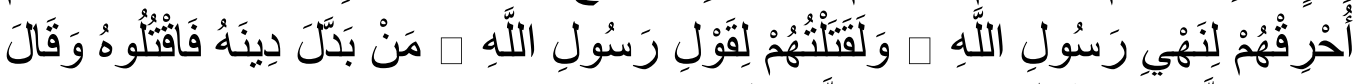

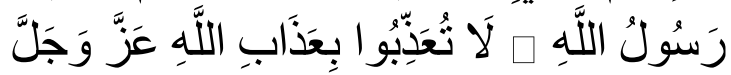

Diriwayatkan oleh 'Ikrimah; bahwa pernah didatangkan kepada 'Ali $\square$ suatu kaum dari kalangan orang-orang zindiq, saat itu mereka membawa kitab-kitab mereka. Maka 'Ali oي memerintahkan untuk menyalakan api untuk membakar mereka serta bukunya. 'Ikrimah menambahkan: berita tersebut terdengar oleh ibn 'Abbas,

${ }^{17}$ Imam Nasa'i, Sunan al-Nasa ’ $i$, Jilid 2, No. Hadis 4082 (Stuttgart: Jam‘iyyatu al-Maknaz alIslami, 2000), 670. 2966, 119.

${ }^{18}$ Imam Ahmad ibn Hanbal, Musnad Ahmad, Tahqiq: Syu'aib Arna'uth, Jilid 5, No. Hadis 
lalu ia berkata; "Seandainya itu adalah aku, maka aku tidak akan membakar mereka karena adanya larangan Rasulullah dan tentu aku akan membunuh mereka berdasarkan sabda Rasulullah "Barangsiapa yang mengganti agamanya, maka bunuhlah dia." Dan Rasulullah bersabda: "Janganlah kalian menyiksa dengan siksaan Allah 'azza wajalla."19

Dari matan di atas, dapat beberapa poin penting yang perlu diperhatikan:

1) Kaum yang dibakar 'Ali adalah orang-orang zindiq.

2) Mereka dibawa dan dibakar beserta buku-buku mereka.

\section{Syarhu al-Hadis}

1. Orang yang dibunuh 'Ali

Dari beberapa matan di atas dapat disimpulkan bahwa orang yang dibakar oleh 'Ali adalah:

a. Dalam Shahih Bukhari: Tidak dijelaskan orang yang dibakar (hanya disebutkan kaum saja)

b. Dalam Sunan Tirmidzi, Sunan Abi Dawud dan Musnad Ahmad: Orang yang dibakar adalah orang yang murtad dari Islam

c. Dalam Sunan al-Nasa'i dan Musnad Ahmad: Orang yang dibakar adalah beberapa orang dari al-Zuth yang menyembah berhala.

d. Dalam Musnad Ahmad: Orang yang dibakar adalah orang-orang Zindiq ${ }^{20}$

Ibn Hajar menjelaskan secara terperinci terkait kejadian tersebut, yaitu menukil dari mu 'jam al-ausath: Sesungguhnya 'Ali ibn Abi Thalib mendengar berita bahwa di Bashrah ada suatu kaum yang keluar dari agama Islam. Maka 'Ali mengutus pasukan ke Bashrah. Sesampainya di Bashrah, kaum yang murtad itu dibawa kepada 'Ali, dan 'Ali pun memberi mereka makan selama dua minggu (agar bertaubat), kemudian ia menyeru mereka untuk kembali lagi memeluk agama Islam, namun mereka menolak. Maka digalilah lubang untuk mereka dan berdiri di atasnya, ia berkata: "Aku akan memenuhi kalian dengan lemak dan daging,"

${ }^{19}$ Imam Ahmad ibn Hanbal, Musnad Ahmad, Tahqiq: Syu'aib Arna'uth, Jilid 5, No. Hadis $2551,119$.

${ }^{20}$ Ibn Hajar memaparkan kata Zindiq mempunyai beberapa $m a$ ' $n a$, berikut penjelasananya:

- Menurut Abu Hatim al-Sijistani diambil dari bahasa Persia.

- Tha'lab mengatakan: Dalam bahasa Arab tidak ada kata zindiq, melainkan Zandaqiyyun, yakni orang yang mempercayai tahayyul, atau orang yang tidak beragama.

- Al-Jauhary mengatakan: Zindiq adalah penganut wathaniyyah (agama Majusi), yaitu adanya Tuhan baik dan Tuhan jahat. Ahlu khair berasal dari cahaya (penguasa terang) dan Ahlu syar berasal dari kegelapan (penguasa kegelapan).

- Para fuqaha', diantaranya Imam Malik dan Syafi'i: Zindiq adalah yang menunjukkan keimanannya dan menyembunyikan kekafirananya.

- Imam Nawawi: Zindiq adalah orang yang tidak beragama. 
kemudian dibawakan kepada mereka makanan agar bertaubat (tetapi masih menolak untuk memeluk Islam), maka dipenggallah lehernya, dan dimasukkan ke dalam lubang tersebut, lalu ditutup dengan kayu dan dibakar. Kemudian ia berkata: "Maha benar Allah 能 dan Rasulnya.",21

Ibn Hajar menambahkan, menurut Abu al-Mudhaffar al-Isfirayini dalam "alMilal wa al-Nihal" bahwa yang dibakar 'Ali adalah kelompok Syi 'ah Rafidlah yang mengakui bahwa 'Ali Tuhan mereka. Mereka adalah kelompok Saba'iyyah, yang dipimpin seorang Yahudi yang mengaku Islam, yaitu 'Abdullah ibn Saba'. Dari Abu Tahir al-Mukhallish dari 'Abdullah ibn Syarik al-'Amiri dari ayahnya berkata: "Dikabarkan kepada "Ali bahwa ada sekelompok orang di pintu masjid yang mengakui bahwa 'Ali Tuhan mereka. Maka 'Ali pun memanggilnya dan berkata: "Celakalah kalian! Apa yang kalian katakan?” Mereka menjawab: "Engkaulah Tuhan kami, pencipta kami dan pemberi rizki kami." "Ali berkata: "Celakalah kalian! Aku adalah hamba sebagaimana kalian, aku makan seperti kalian, aku juga minum seperti kalian. Apabila aku taat kepada Allah 能, maka apabila Allah 敬 berkehendak akan membalasku, tetapi apabila aku bermaksiat, aku takut Allah 敬 akan mengadzabku. Maka bertaqwalah kalian dan kembalilah (memeluk Islam)." Tetapi mereka menolak. Keesokan harinya mereka datang lagi. Maka menghadaplah Qanbar (anak buah 'Ali ibn Abi Thalib on dan berkata: "Demi Allah 紫, mereka kemudian kembali lagi lalu mengucapkan hal yang sama.” "Ali berkata: "Tangkaplah mereka." Tetapi mereka tetap mengatakan hal serupa (mengakui "Ali Tuhan). Maka untuk ketiga kalinya "Ali ibn Abi Thalib menegaskan: "Apabila kalian masih mengatakan hal tersebut, maka sungguh aku kubunuh kalian semua dengan cara yang sangat keji." Tetapi mereka masih menolak. 'Ali pun berkata: "Wahai Qanbar! Bawakan kepadaku perbuatan yang dapat menyiksa mereka!" Maka dibuatlah lubang antara pintu masjid dan istana. Ia berkata: "Galilah yang dalam!" Kemudian dibawakan kayu berserta api yang dibakar di dalam lubang tersebut, dan "Ali berkata: "Aku akan melemparkan kalian ke dalam lubang tersebut atau kalian memilih kembali (memeluk Islam)," tetapi mereka masih menolak. Maka dilemparkanlah mereka ke dalamnya sampai terbakar. Sanad ini hasan. ${ }^{22}$

Masih menurut penjelasan ibn Hajar, sedangkan riwayat dalam Mushannaf ibn Abi Syaibah dari jalur Qatadah yang menjelaskan bahwa orang yang dibawa kepada 'Ali adalah orang-orang dari Zuth, sanadnya munqathi'. Kalau pun sanadnya Shahih, maka itu kisah yang lain. ${ }^{23}$ Setelah penulis telusuri, hadis ini juga

${ }^{21}$ Imam Tabrani, al-Mu 'jam al-Ausath, No. Hadis 7285 (Kairo: Dar al-Haramain, t.th.), 2191.

${ }^{22}$ Ibn Hajar, Fath al-Bari, Jilid 12 (t.t.: Dar al-Rayyan li al-Turath, t.th.), 279. Lihat juga: Mubarakfuri, Tuhfatu al-Ahwadzi, Jilid 5, 19.

${ }^{23}$ Ibid. 
ada dalam sunan al-Nasa'i dari jalur Qatadah dari 'Anas ibn Malik, seluruh perawinya tsiqah, derajatnya Shahih.

2. Berkenaan dengan cara membunuhnya, dijelaskan oleh ibn Hajar

a. Dalam riwayat 'Ayyub dijelaskan bahwa 'Ali membunuh dengan cara membakar. Ibn Hajar menukil sebuah riwayat dari Mushannaf ibn Abi Syaibah" ${ }^{24}$ : "Dulu seseorang yang menyembah berhala-berhala mereka dengan sembunyi, dan mengambil keuntungan darinya. Kemudian orang tersebut ditangkap dan dihadirkan di hadapan khalifah 'Ali ibn Abi Thalib alu 'Ali bin Abi Thalib memenjarakan mereka. 'Ali bin Abi Thalib bermusyawarah dengan para sahabat, diantara mereka ada yang mengusulkan: "Bunuhlah mereka!". Maka 'Ali bin Abi Thalib berkata: "Tidak, aku tidak akan membunuh mereka seperti dihukumnya Ibrahim (bapak kami) dihukum," namun pada akhirnya "Ali ibn Abi Thalib pun membakar mereka."25

b. Sedangkan dalam riwayat "Ammar dengan cara dimasukkan ke dalam lubang kemudian menusuknya. ${ }^{26}$ Setelah ditelusuri, penulis menemukan dalam sunan al-Baihaqi ${ }^{27}$, sebagaimana yang dijelaskan ibn Hajar dalam riwayat 'Ammar: 'Ammar berkata: Tidak dibakar, melainkan dimasukkan ke dalam lubang, kemudian ditusuk dan mengasapinya. ${ }^{28}$

\section{Mengkaji Hukuman Mati Bagi Orang Murtad}

1. Sebelum masuk ke dalam kajian hadis terkait hukuman mati bagi orang yang murtad, maka penulis berusaha melihat terlebih dahulu dalil-dalil yang ada dalam al-Qur'an.

a. Surat al-Baqarah 217: Barangsiapa yang murtad di antara kamu dari agamanya, lalu dia mati dalam kekafiran, maka mereka itulah yang sia-sia amalannya di dunia dan di akhirat, dan mereka itulah penghuni neraka, mereka kekal di dalamnya [Al Baqarah217]

b. Surat Ali 'Imran 90: Sesungguhnya orang-orang kafir sesudah beriman, kemudian bertambah kekafirannya, sekali-kali tidak akan diterima taubatnya; dan mereka itulah orang-orang yang sesat [Al 'Imran90]

c. Surat al-Nisa' 137: Sesungguhnya orang-orang yang beriman kemudian kafir, kemudian beriman (pula), kamudian kafir lagi, kemudian bertambah

${ }^{24}$ Ibid., Jilid 6, 175.

${ }^{25}$ Ibn Abi Syaibah, Mushannaf ibn Abi Syaibah, No. Hadis 28431 (Riyadl: al-Rusyd, 2004), 4145 .

${ }^{26}$ Ibn Hajar, Fath al-Bari, Jilid 6 (t.t.: Dar al-Rayyan li al-Turath, t.th.), 175.

27 Dalam mu'jam al-Ma'ani yang dimaksud dengan نجَّ adalah نحل النُخانَ يصل إليه (mengasapinya).

${ }^{28}$ Imam Baihaqi, Sunan al-Baihaqi, No. Hadis 16613 (Makkah: Maktabah Dar al-Baz, t.th.), 6516. 
Moderasi Beragama: Meninjau Hadis-Hadis Hukuman Mati Bagi Orang Murtad

kekafirannya, maka sekali-kali Allah tidak akan memberi ampunan kepada mereka, dan tidak (pula) menunjuki mereka kepada jalan yang lurus [An Nisa"137]

d. Surat al-Nahl 106: Barangsiapa yang kafir kepada Allah sesudah dia beriman (dia mendapat kemurkaan Allah), kecuali orang yang dipaksa kafir padahal hatinya tetap tenang dalam beriman (dia tidak berdosa), akan tetapi orang yang melapangkan dadanya untuk kekafiran, maka kemurkaan Allah menimpanya dan baginya azab yang besar [An Nahl106]

e. Surat Ali 'Imran 144: Muhammad itu tidak lain hanyalah seorang rasul, sungguh telah berlalu sebelumnya beberapa orang rasul. Apakah Jika dia wafat atau dibunuh kamu berbalik ke belakang (murtad)? Barangsiapa yang berbalik ke belakang, maka ia tidak dapat mendatangkan mudzarat kepada Allah sedikitpun, dan Allah akan memberi balasan kepada orang-orang yang bersyukur [Al 'Imran144]

Dari beberapa ayat yang disebutkan di atas, menunjukkan bahwa orang yang keluar dari Islam, memiliki konsekuensi hukum. Yaitu akan sia-sia amalannya selama di dunia sebagaimana yang dijelaskan pada ayat pertama. Sedangkan ayat kedua dan ketiga menjelaskan bahwa jika orang murtad setelah ia beriman sebelumnya, dan semakin bertambah kekafirannya, maka taubatnya tidak akan diterima. Ayat selanjutnya menjelaskan bahwa orang yang murtad akan mendapatkan murka Allah 能. Dan ayat terakhir menyebutkan bahwa orang yang murtad tidak dapat mudlarat sama sekali. Tetapi yang perlu dicatat, tidak ada satupun ayat di atas yang menyebutkan secara sharih, bahwa orang yang keluar dari Islam harus dibuunuh.

Jika dilihat dari konteks kejadian, terlihat bahwa ayat tersebut turun pada periode Madinah, hanya surat al-Nahl 106 yang Makkiyyah. ${ }^{29}$

2. Disisi lain, dapat ditemukan beberapa hadis yang menyebutkan bahwa Rasulullah tidak membunuh orang yang keluar dari Islam

a. Rasulullah tidak membunuh orang yang menarik bai'atnya "Dari Jabir ibn 'Abdullah suatu ketika ada seorang Arab Badui yang datang Jepara Rasulullah untuk berbai'at. Lalu orang tersebut terserang demam di Kota Madinah. Maka menghadaplah ia kepada Rasulullah berujar: "Wahai Rasulullah, tariklah bai'atku". Rasulullah menolaknya. Lalu orang tersebut kembali lagi sampai tiga kali, dan Rasulullah tetap

${ }^{29}$ M. Robith Fuadi Abdullah, "Meninjau Hukuman Mati Bagi Murtad (Kajian Hadis Tematik)", de Jure, Jurnal Syari 'ah dan Hukum, Vol. 4, No. 1 (Juli 2012), 29. 
menolaknya. Rasulullah kemudian bersabda: "Sesungguhnya Kota Madinah seperti mesin pemanggang api yang membersihkan kotoran dan menyaring sesuatu yang baik".,30

Setelah hadis tersebut ditelaah, disimpulkan bahwa:

1) Rasulullah tidak menghukum mati orang Arab Badui, berarti hukuman mati tidak mutlak berlaku bagi orang yang keluar dari Islam.

2) Dalam hadis tersebut Rasulullah tidak memerintahkan sahabat untuk menangkap dan membunuhnya.

b. Seorang nasrani yang masuk Islam, bahkan sempat menjadi orang kepercayaan Rasulullah sebagai penulis Wahyu, tetapi kemudian ia keluar dari Islam dan kembali lagi ke Nasrani.

dari Anas berkata, suatu ketika ada seorang Nasrani masuk Islam. Dia biasa menulis untuk Nabi (sebagai penulis wahyu). Namun dia keluar dari agama Islam dan kembali ke Nasrani. Ia berujar; "Tidak ada yang diketahui Muhammad melainkan apa yang aku tulis untuknya". Lalu Allah 能 menjadikan orang tersebut meninggal dunia. Dikuburlah jasad orang tersebut oleh temanya. Tetapi esoknya, jasad si Nasrani dimuntahkan bumi. Maka teman-temannya menuduh bahwa hal tersebut perrbuatan Muhammad dan para sahabat, lalu dikuburkan lagi. Esoknya jasadnya dimuntahkan lagi, hingga terjadi tiga kali. Lalu jasad tersebut mereka campakkan. $^{31}$

Pada hadis ini Rasulullah tidak langsung memerintahkan para sahabat membunuh si Nasrani yang kembali ke agamanya.

3. Hadis-hadis yang menjelaskan bahwa orang yang murtad harus dibunuh.

a. Hadis bab (awal pembahasan)

b. Dijelaskan dalam sebuah riwayat dengan sanad mauquf:

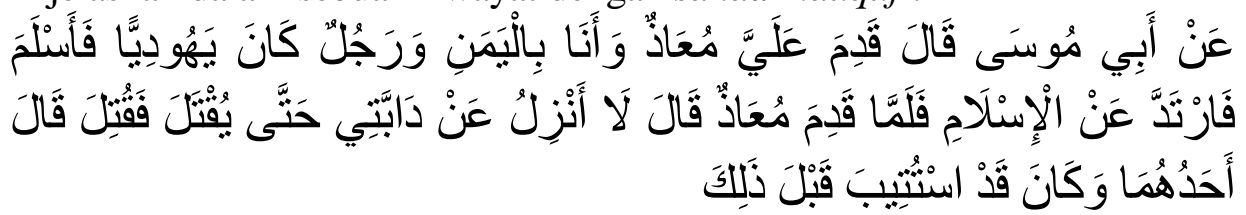

"dari Abu Musa ia berkata, "Mu'adz pernah datang kepadaku saat aku berada di Yaman dan ada seorang yahudi yang telah masuk Islam kemudian murtad. Saat Mu'adz tiba, ia berkata, "Aku tidak akan turun dari tungganganku ini hingga ia (yahudi itu) dibunuh." Yahudi itu akhirnya dibunuh. Salah seorang dari keduanya (Abu Musa dan Mu'adz) berkata,

${ }^{30}$ Muhammad ibn Isma'il al-Bukhari, Shahih Bukhari, Jilid 3, No. Hadis 7297, 1457.

${ }^{31}$ Ibid., Jilid 2, No. Hadis 3660, 712. 
Moderasi Beragama: Meninjau Hadis-Hadis Hukuman Mati Bagi Orang Murtad

"Yahudi itu telah diminta untuk bertaubat sebelum diekskusi mati"., "32

Hadis ini mengisahkan tentang perlawanan terhadap nabi palsu.

Mu'adz ibn Jabal diperintahkan Rasulullah untuk meredam al-Aswad al'Unsiy, seorang nabi palsu. Namun pada akhirnya, di akhir hayat Rasulullah

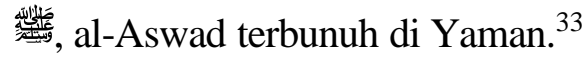

c. Haram membunuh seorang Muslim, kecuali pada tiga perkara

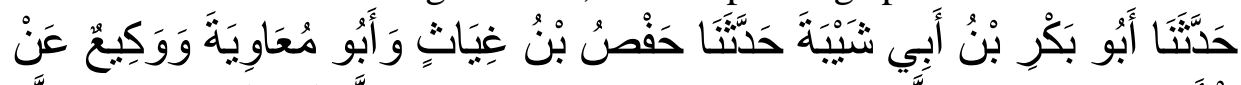

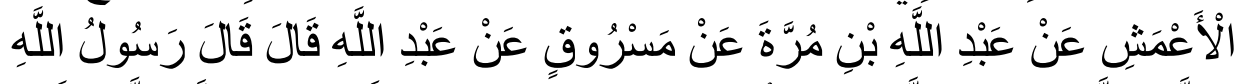

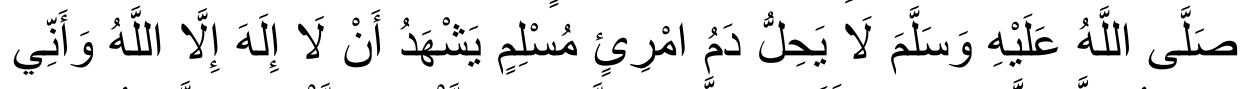

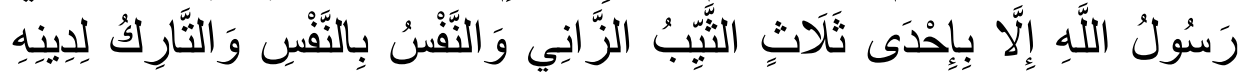

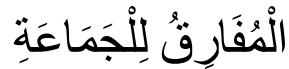

Telah menceritakan kepada kami Abu Bakar ibn Abi Syaibah telah menceritakan kepada kami Hafs\{ ibn Ghiyats dan Abu Mu'awiyah dan Waki' dari al-A'masy dari 'Abdullah ibn Murrah dari Masruq dari 'Abdullah dia berkata, "Rasulullah bersabda: "Tidak halal darah seorang muslim yang telah bersaksi bahwa tiada Tuhan yang berhak untuk disembah selain Allah dan aku adalah utusan Allah, kecuali satu dari tiga orang berikut ini; seorang janda yang berzina, seseorang yang membunuh orang lain dan orang yang keluar dari agamanya, memisahkan diri dari Jama'ah (murtad). ${ }^{134}$

Pada hadis pertama (hadis bab), kita dihadapkan pada fakta bahwa tidak ada konteks yang diketahui tentang mengapa, dan dalam kasus apa hukum ini ditetapkan, sehingga kita sulit mengetahui latar belakang kemunculan hukum tersebut secara pasti. Yang jelas adalah bahwa hadis tersebut menyatakan bahwa orang yang mengganti agamanya dari Islam menjadi non Islam, maka baginya hukuman mati. Namun jika dilihat dengan seksama, terdapat dalam hadis lain yang menjelaskan bahwa Rasulullah tidak menghukum mati orang yang keluar dari agama Islam, maka tidak tepat jika hadis pertama (hadis bab) diterapkan dalam segala kondisi (dipahami secara mutlak. ${ }^{35}$

${ }^{32}$ Abu Dawud, Sunan Abi Dawud, Jilid 2, No. Hadis 4357 (Stuttgart: Jam‘iyyatu al-Maknaz al-Islami, 2000), 727.

${ }^{33}$ Ja'far Assagaf, "Kontekstualisasi Hukum Murtad dalam Perspektif Sejarah Sosial Hadis", Ijtihad - Jurnal Wacana Hukum Islam dan Kemanusiaan, Vol. 14, No. 1 (Juni 2014), 34.

${ }^{34}$ Muslim ibn Hajjaj, Shahih Muslim, Jilid 2, No. Hadis 4468, 726.

${ }_{35}$ M. Robith Fuadi Abdullah, "Meninjau Hukuman Mati Bagi Murtad (Kajian Hadis Tematik)", de Jure, Jurnal Syari 'ah dan Hukum, Vol. 4, No. 1, 31. 
Hal tersebut juga dikuatkan pada hadis "poin c" riwayat al-Nasa'i yang

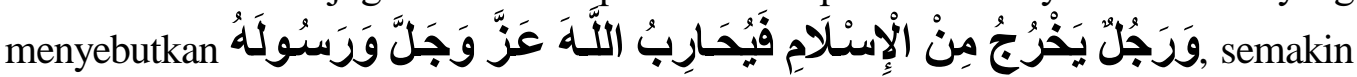
mempertegas bahwa yang dimaksud dengan orang murtad yang layak dibunuh

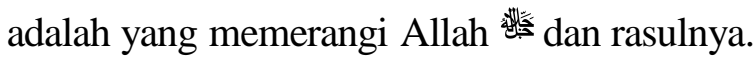

\section{Taubat Orang Yang Murtad}

Ibn Baththal menjelaskan bahwa jumhur ulama sepakat untuk memberikan kesempatan bertaubat bagi orang yang murtad, meskipun ada sebagaian golongan, yakni dari Ahlu Dhahir yang menetapkan bahwa orang yang murtad harus tetap dibunuh. Berikut penjelasannya:

1. Jumhur: Apabila bertaubat maka diterima taubatnya, namun jika tidak, maka dibunuh. Menurut ibn al-Qashshar, alasan jumhur memberikan kesempatan bertaubat bagi orang yang murtad berdasarkan ijma' sukuti.

Suatu ketika 'Umar mengirimkan surat berkenaan dengan orang yang murtad, ia mengatakan: "Tangkaplah mereka selama tiga hari, berilah mereka makan roti setiap harinya, barangkali mereka bertaubat kepada Allah 能." Pada waktu itu, tidak ada satu pun dari sahabat yang mengingkari / menolak perbuatan 'Umar. Inilah yang dimaksud dengan ijma' sukuti. Dengan demikian dapat disimpulkan bahwa para sahabat memahami hadis Rasulullah

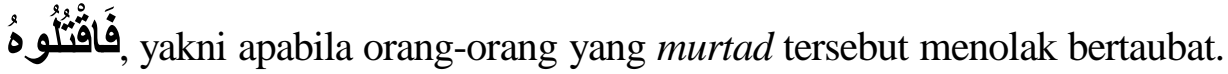

Pendapat ini juga sesuai dengan firman Allah 態点

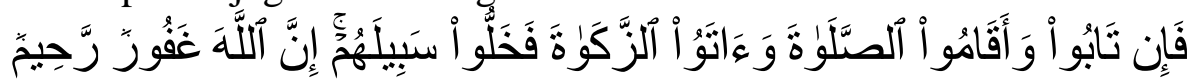

Jika mereka bertaubat dan mendirikan syolat dan menunaikan zakat, maka berilah kebebasan kepada mereka untuk berjalan. Sesungguhnya Allah Maha Pengampun lagi maha Penyayang [al-Tawbah 5]

2. Al-Hasan, Tawus, dan Ahlu al-Dhahir: Wajib dibunuh (sebagaimana Dhahir hadis).

3. Dari ibn 'Abbas dan 'Atha': Apabila ketika lahir dia Muslim, maka tidak diterima taubatnya. Namun jika sebaliknya, maka diterima taubatnya. ${ }^{36}$

\section{Siapa Yang Berhak Mengeksekusi?}

Imam Nawawi menjelaskan dalam Syarh Shahih Muslim, bahwa yang berhak memberikan hukuman:

1. Diriwayatkan dari 'Ali dan Qadli 'Iyadl: Yang berhak memberikan hukuman dalah pemimpin negeri. Demikian pendapat Imam Malik, Imam Syafi‘i, Abu

${ }^{36}$ Ibn Hajar, Fath al-Bari, Jilid 12, 279. 
Moderasi Beragama: Meninjau Hadis-Hadis Hukuman Mati Bagi Orang Murtad

Hanifah dan para ulama yang lain.

2. Al-Kufiyyun: Tidak ada yang berhak melakukannya kecuali fuqaha' alamshar. $^{37}$

\section{Memerangi Orang Yang Murtad Sepeninggal Rasulullah}

Memerangi orang murtad (keluar dari agama Islam) juga dilakukan oleh para khalifah setelah Rasulullah

1. Periode Abu Bakar

Pada awal kekhalifahan Abu bakar, hal yang menjadi perhatian sang khalifah adalah memerangi orang-orang yang murtad. Namun perlu diketahui, bahwa perang tersebut adalah perang melawan kaum murtad yang membangkang dan mengancam stabilitas dan keamanan negara. Diantaranya adalah Musailamah al-Kadzdzab yang telah mempersiapkan empat puluh ribu prajurit untuk memerangi kaum muslimin. Bahkan sebagian dari mereka, seperti suku 'Abbas dan Dzibyan yang menyerang terlebih dahulu. ${ }^{38}$

2. Periode 'Umar ibn Khaththab

"Dari al-Tsawry dari Dawud dari al-Sya'by dari 'Anas $\square$ berkata: Abu Musa telah memerintahkan kepadaku untuk menaklukkan suatu kaum, maka 'Umar bertanya kepadaku, pada waktu itu ada enam orang dari Bani Bakr ibn Wa'il telah keluar dari Islam, dan mereka menyusul kaum musyrikin. 'Umar berkata: "Apa yang dilakukan orang-orang dari Bani Bakr ibn Wa'il?", aku berkata: "Wahai 'Amir al-Mu'minin! Mereka adalah kaum yang keluar dari Islam dan menyusul orang-orang musyrik, tidak ada jalan bagi mereka kecuali dibunuh." Maka 'Umar berkata: "Aku lebih suka menangkap mereka hiduphidup sampai terbitnya matahari yang berwarna kuning atau putih". Aku berkata: "Wahai 'Amir al-Mu'minin apa yang harus aku lakukan apabila aku menangkap mereka?", ia berkata: "Aku mempersilahkan mereka masuk dari pintu yang mereka keluar darinya (bertaubat), apabila mereka melakukan hal tersebut, aku terima (dengan baik), tetapi apabila tidak maka akan aku masukkan ke dalam penjara"., 39

Pada riwayat di atas, 'Umar ibn Khaththab tidak serta merta membunuh orang yang keluar dari agama Islam (murtad), melainkan dengan cara lain yaitu memenjarakan mereka sebagai bentuk hukuman.

\section{Periode "Ali ibn Abi Talib}

${ }^{37}$ Imam Nawawi, Syarh Shahih Muslim, Jilid 12, 525.

38 M. Robith Fuadi Abdullah, "Meninjau Hukuman Mati Bagi Murtad (Kajian Hadis Tematik)", de Jure, Jurnal Syari 'ah dan Hukum, Vol. 4, No. 1, 32.

39 'Abdu al-Razzaq, Mushannaf 'Abdu al-Razzaq, No. Hadis 18083 (Beirut: al-Maktab alIslamy, t.th.) 3179 . 
Sebelumnya pada hadis bab telah dijelaskan bahwa kaum yang dihukum 'Ali ibn Abi Talib adalah orang-orang zindiq. Ada pula yang berpendapat mereka adalah orang Syi'ah yang mengakui 'Ali sebagai Tuhan. Tentu hal tersebut sangat meresahkan masyarakat, serta menyebabkan kekacauan dan penyimpangan aqidah umat Islam. Sehingga 'Ali ibn Abi Talib membunuh mereka.

\section{Kesimpulan}

Agama Islam merupakan agama yang rahmatan lil 'alamin, agama yang menjunjung tinggi kebebasan beragama. Allah 此 berfirman: Untukmu agamamu, dan untukkulah, agamaku" [Al Kafirun 6]

Oleh kareana itu, antara kewajiban memelihara agama dan prinsip kebebasan bergama merupakan dua hal yang tidak bisa dipisahkan. Namun akan terlihat suatu pertentangan apabila prinsip kebebasan beragama itu dikaitkan dengan hukuman mati bagi orang yang murtad. Jikalau seseorang berpindah dari agama Islam ke agama yang lain disebabkan alasan pribadi, dan kemudian diberlakukan hukuman mati bagi orang tersebut, tidakkah hal tersebut bertentang dengan kebebasan beragama?

Syeikh Yusuf Qardlawi menjelaskan bahwa hukuman mati bagi orang yang keluar dari agama Islam dapat diterapkan apabila memenuhi dua syarat:

1. Keluar dari agama Islam baik dengan ucapan ataupun perbuatan;

2. Melakukan perbuatan criminal, seperti: memecah-belah umat islam, membuat kekacauan, kerusakan, tidak taat kepada negara, serta membantu musuh dalam memerangi kaum Muslimin. ${ }^{40}$

Penulis menyimpulkan bahwa baik ayat-ayat di dalam Alquran maupun hadis-hadis Nabi tidak serta merta langsung memerintahkan untuk membunuh orang yang keluar dari agama Islam, kecuali jika orang tersebut melakukan pembangkangan, bersekutu dengan musuh dan semisalnya.

\section{Daftar Pustaka}

Abdullah, M. Robith Fuadi. "Meninjau Hukuman Mati Bagi Murtad (Kajian Hadist Tematik).” De Jure: Jurnal Hukum Dan Syar'iah 4, no. 1 (1 Juni 2012). https://doi.org/10.18860/j-fsh.v4i1.2153.

'Abdurrazzaq. Mushannaf 'Abdu al-Razzaq. Beirut: al-Maktab al-Islamy, t.t.

'Abdurrazzaq, Nu'man. Ahkam al-Murtad fi al-Syari' ah al-Islamiyyah. Riyadl: Dar al-'Ulum, 1983.

${ }^{40}$ Singgih Basuki, "Kebebasan Beragama Dalam Masyarakat (Studi Tentang Pindah Agama dan Konsekuensinya Menurut Pemikir Muslim Kontemporer)”, Religi, Vol. IX, No. 1 (Januari 2013), 66. 
Moderasi Beragama: Meninjau Hadis-Hadis Hukuman Mati Bagi Orang Murtad

Ahadiyanto, Nuzul. Hubungan Dimensi KepribadianThe Big Five Personality Dengan Tingkat Kesejahteraan Psikologis Narapidana. Jurnal AlHikmah, 2020, 18.1: 117-130.

Al Ahsani, Nasirudin. Kepemimpinan Perempuan Pada Masyarakat dalam Perspektif Sa īd Ramaḍān Al-Būṭī (Telaah Hadis Misoginis). Jurnal AlHikmah, 2020, 18.1: 57-74.

Al-Mizzi. Tahdzib al-Kamal fi Asma'i al-Rijal. Vol. 15. Beirut: Mu'assasah alRisalah, 1980.

Alwi, Muhammad Muhib. Pemberdayaan Ekonomi Masyarakat Berbasis Masjid di Tengah Pandemi Covid-19. Jurnal Al-Hikmah, 2020, 18.1: 99-116. Assagaf, Ja'Far. "Kontekstualisasi Hukum Murtad Dalam Perspektif Sejarah Sosial Hadis." Ijtihad: Jurnal Wacana Hukum Islam Dan Kemanusiaan 14, no. 1 (30 Juni 2014): 21-39. https://doi.org/10.18326/ ijtihad.v14i1.21-39.

Baihaqi, Imam. Sunan al-Baihaqi. Makkah: Maktabah Dar al-Baz, t.t.

Basuki, A. Singgih. "KEBEBASAN BERAGAMA DALAM MASYARAKAT (Studi Tentang Pindah Agama Dan Konsekuensinya Menurut Pemikir Muslim Kontemporer)." Religi: Jurnal Studi Agama-Agama 9, no. 1 (31 Januari 2013): 59-79. https://doi.org/10.14421/rejusta.2013.0901-04.

Dawud, Abu. Sunan Abi Dawud. Stuttgart: Maknaz Islamy, 2010.

Dawud, Mochammad. Menerapkan Manajemen Strategi Penyiaran untuk Penyiaran Dakwah. Jurnal Al-Hikmah, 2019, 17.1: 109-140.

Dawud, Mochammad; Choliq, Abdul. Manajemen Strategi Ala NU Tv 9 Menghadapi Televisi Swasta Lokal di Surabaya. Jurnal Al-Hikmah, 2020, 18.1: 75-98.

Elanda, Yelly. Komodifikasi Agama pada Perumahan Syariah di Surabaya. Jurnal Al-Hikmah, 2019, 17.1: 41-62.

Fauzi, Ahmad. Problematika Dakwah di Tengah Pandemi Covid 19 Mewabah. Jurnal Al-Hikmah, 2020, 18.1: 27-36.

Hadi, H. Sofyan. Manajemen Strategi Dakwah di Era Kontemporer. Jurnal AlHikmah, 2019, 17.1: 79-90.

Hajar, Ibn. Fathu al-Bari. Dar al-Rayyan li al-Turats, t.t.

Hanbal, Imam Ahmad ibn. Musnad Ahmad. Vol. 4. Beirut: Mu'assasah al-Risalah, 1999.

Isfironi, Mohammad. Kota Santri, Bumi Shalawat Nariyah dan Bule-Dhika. Jurnal Al-Hikmah, 2019, 17.1: 1-20.

Jannah, Hasanatul. Pondok Pesantren Sebagai Pusat Otoritas Ulama Madura. Jurnal Al-Hikmah, 2019, 17.1: 91-108.

Kuwaitiyyah, Wizaratul al-Awqaf. Mausu'ah Kuwaitiyyah. Vol. 22. Kuwait: Wizaratu al-Auqaf wa al-Syu'un al-Islamiyyah, 2007.

Mubarakfuri. Tuhfatu al-Ahwadzi. Vol. 5. Beirut: Dar al-Kutub al-'Ilmiyyah, t.t.

Muslim, Imam. Sahih Muslim. Stuttgart: Maknaz Islamy, 2010.

Nasa'i, Imam. Sunan Nasa'i. Stuttgart: Maknaz Islamy, 2010. 
Nawawi, Imam. Syarh Shahih Muslim. Dar al-Khair, t.t.

Setiawan, Eko. Makna Nilai Filosofi Wayang Kulit Sebagai Media Dakwah. Jurnal Al-Hikmah, 2020, 18.1: 37-56.

Tabrani, Imam. al-Mu jam al-Ausath. Kairo: Dar al-Haramain, t.t.

Tirmidzi, Imam. Sunan Tirmidzi. Stuttgart: Maknaz Islamy, 2010.

Wensink. al-Mu jam al-Mufahras li Alfadzi al-Hadis. Vol. 5. Leiden: Bril, 1936.

Wazis, Kun. Perlawanan Ahli Hadis terhadap Gerakan Radikalisme Dalam Konstruksi Media Online. Jurnal Al-Hikmah, 2019, 17.1: 20-40. 